\title{
Hybrid Lighting System with Solatube for Room Without Ventilation as Smart Energy Saving
}

\author{
DINI FAUZIAH, FEBRIAN HADIATNA, WALUYO, MUHAMAD WAHYUDIN \\ Institut Teknologi Nasional Bandung, Indonesia \\ Email : dinifauziah@itenas.ac.id
}

Received 23 September 2020 | Revised 7 Desember 2020 | Accepted 30 Desember 2020

\begin{abstract}
ABSTRAK
Dalam praktiknya, banyak ruangan yang tidak memiliki ventilasi cahaya sehingga menggunakan sumber cahaya hingga selama 24 jam. Penelitian ini bertujuan untuk merancang sistem yang dapat meminimalkan penggunaan listrik untuk penerangan dengan menggunakan sistem solatube. Solatube akan memberikan sinyal pada dimmer yang mengatur kapasitas cahaya lampu sehingga tidak selalu membutuhkan performa penuh. Berdasarkan hasil pengujian, sistem solatube dapat menghasilkan nilai intensitas cahaya maksimal yang dapat memenuhi standar untuk ruang baca yaitu lebih dari 350 Lux dengan persentase penerangan menjadi hanya 1\% - 79\%, terutama selama penggunaan beban siang hari. Hal ini menunjukkan bahwa dengan penggunaan solatube penggunaan daya untuk penerangan dapat dikurangi, sehingga meningkatkan penghematan energi dan biaya. Kemudian alat ini dilengkapi dengan data logger yang dapat diakses melalui internet untuk memantau penggunaan listrik secara realtime sehingga dapat dilakukan monitoring dan evaluasi untuk pengembangan selanjutnya.
\end{abstract}

Kata kunci: Sistem Pencahayaan, Solatube, Penghematan Energi, Data Logger.

\begin{abstract}
In practice, many rooms do not have light ventilation, so they use light sources for up to 24 hours. This study aims to design a sistem that can minimize the use of electricity for lighting using a solatube sistem. Solatube provide a signal to the dimmer that regulates the light capacity of the lamp thus it does not always require full performance. Based on the test results, the solatube sistem can produce a maximum light intensity value that can meet the standards for the reading room, which is more than 350 Lux with the percentage of light being only 1\% - 79\%, especially during the use of daytime loads. This shows that with solatube lighting sistem, power consumption for lighting can be reduced, thereby increasing energy and cost savings. Furthermore this tool is equipped with a data logger that can be accessed via the internet to monitor realtime electricity usage thus that it can be monitored and evaluated for further development
\end{abstract}

Keywords: lighting sistem, solatube, energy saving, data logger. 
Sistem Pencahayaan untuk Ruangan tanpa Ventilasi Cahaya Menggunakan Solatube Sebagai Upaya Penghematan Energi

\section{INTRODUCTION}

The need for electrical energy continues to increase all the time. If we continue to rely on fossil fuels, one day that energy will run out so renewable energy becomes a solution for future energy sources. One type of renewable energy is energy from sunlight which can be converted into electricity. In addition, sunlight itself can also be used as natural lighting in a room as a step to reduce energy consumption. Reducing energy consumption is becoming important, as a guarantee that we will have enough energy to support life in the future. Although renewable energy sources are increasingly being used, the best way to reduce the use of energy is by reducing energy consumption (Hodges, 2017).

In Indonesia, the main source of electrical energy still comes from fossil fuels which in the process of combustion produce carbon dioxide emissions. Reducing the electricity load for lighting is one step towards realizing energy-efficient and sustainable buildings. In addition, in a tropical country like Indonesia the potential for using natural lighting is very high, so it can be considered as the main lighting especially during the midday. Natural lighting that comes from sunlight has the potential to significantly contribute to reducing carbon dioxide emissions by 223 million tonnes and ultimately aims to prevent global warming. Based on research, the need for lighting consumes up to $40 \%$ of the total electricity demand or around $24,000 \mathrm{MW}$ of electricity demand so that if this figure can be reduced or even lost it will have a large enough impact on the environment (Wong, 2017). In addition to room lighting needs, sunlight can also be adjusted in such a way as to minimize energy consumption for heating and cooling purposes during the day (Chi, Moreno, \& Navarro, 2018)

Lighting is an important factor in space design. A room that has been designed cannot fulfill its function properly if access to lighting is not available. There are three types of room lighting sources, namely lamp light, curtain wall and sunlight. These three things aim to achieve good visual comfort (Babarinde \& Alibaba , 2018). However, there are several problems that can occur if lighting uses direct sunlight, firstly exposure to excessive brightness of sunlight is not good for health because it can become light pollution (Kumar Singh \& Kumar Jain, 2013), then the problem of excess heat which can cause thermal discomfort. So that the advantages of natural lighting can be felt if the quality is adjusted in such a way (Wong, 2017). So it can be concluded that the optimal lighting design includes optimizing the quantity of light received by the room, maintaining visual comfort and coolness, and saving energy.

Many factors make the importance of natural lighting for a room. However, in some cases this is difficult to achieve, for example in underground spaces, as well as spaces that are too narrow and light ventilation is blocked by objects in the room, causing darkness even during the day. This can cause a decrease in light and thermal comfort which in the long run can affect physical and mental health (Susanto, Febrianti Rahayu, \& Widyarko, 2018).

One method used to maximize the use of sunlight in a room without light ventilation is to use a Solatube (Iqbal \& Ahmed, 2014). Solatube is a pipe used to transport sunlight to another place with the aim of minimizing light leakage. The pipes made by materials that reflect light well so light from the roof or outside can enter the room. The advantage of solatube is that it can avoid excess light compared to direct sunlight, including maintaining excess room temperature rise due to solar heat which can increase the burden of air conditioning because only the light spectrum is delivered while the sun's heat is only found in the receiving pipe. Then it can save energy consumption, has high economic value with a payback period of about 3 years (Babarinde \& Alibaba, 2018) (Kumar Singh \& Kumar Jain, 2013). Solatube is also very suitable to be applied to Smart City because it fits the concept of energy saving (Alzaed \& Balabel, 2020). Based on the research, the combination of solatube use and 
lamp dimmer settings has the greatest potential to save electricity by $27 \%$ compared to twostep control and control on off (Young Shin, Young Yun, \& Tai Kim, 2011). One application of this lighting combination is in an underground parking building with an annual energy savings of $60.4 \%$ (Ji, et al., 2016).

So in this study an energy-efficient lighting system was created by combining light dimmer and solatube control with the aim of maximizing natural resources of sunlight as a source of light in a room that does not have light ventilation so it is expected that the desired light intensity can be achieved with less power consumption. Then to support the development of smart city this tool added an online monitoring component that can monitor load usage in real time remotely so it can evaluate the use of electrical energy after adding the solatube. For further development, a color sensor module can be added to adjust the color characteristics for a certain area in order to obtain precise color gradations according to lighting needs. (Zheng, Wujun, Zhou, \& Yan, 2019).

\section{RESEARCH METHOD}

In this study, a lighting system will be made for rooms without light ventilation, such as basements, or other rooms that do not have access to windows, even can be applied to daylight lighting on animal farms (Wachenfelt, 2015). This system combines sunlight produced by the solatube with light control so that the desired lux value is achieved. For lamp control, we do not use the on-off system because it can cause inconvenience during the onoff process. In addition, the switching frequency that occurs can reduce the life of the lamp. So that better control is to use a control dimmer (Nizam Kamaruzzaman, Edwards, \& Ahmad Zawawi, 2015) (Chen, Liu, Pei, Cao, \& Chen, 2014).

\subsection{Block Diagram of the System}

Figure 1 shows a block diagram of the system made consisting of a solatube system which is a medium for reflecting and collecting sunlight into the room. Then the control and monitoring section provides automatic settings for the lights to make adjustments to the intensity of the light produced.

\subsubsection{Solatube System}

Solatube is a pipe-shaped material made of metal. Solatube works by reflecting sunlight on sheet metal material. This metal sheet is then attached to the dome of the house to reflect sunlight towards the ceiling of the house. The advantages of solatube are also relatively cheaper prices and a faster and easier installation process. Solatube also does not cause leaks in the area of the house because it only functions to reflect light (Wachenfelt, 2015). Sunlight as a light source will enter the transmission line and channel it into the pipe which contains a mirror in it as a reflector. Then the light in the pipe will be channeled into the room. The results of the light intensity produced by the solatube system can be used as a set point to the control system to meet room light intensity needs. Figure 2 shows the solatube construction. 


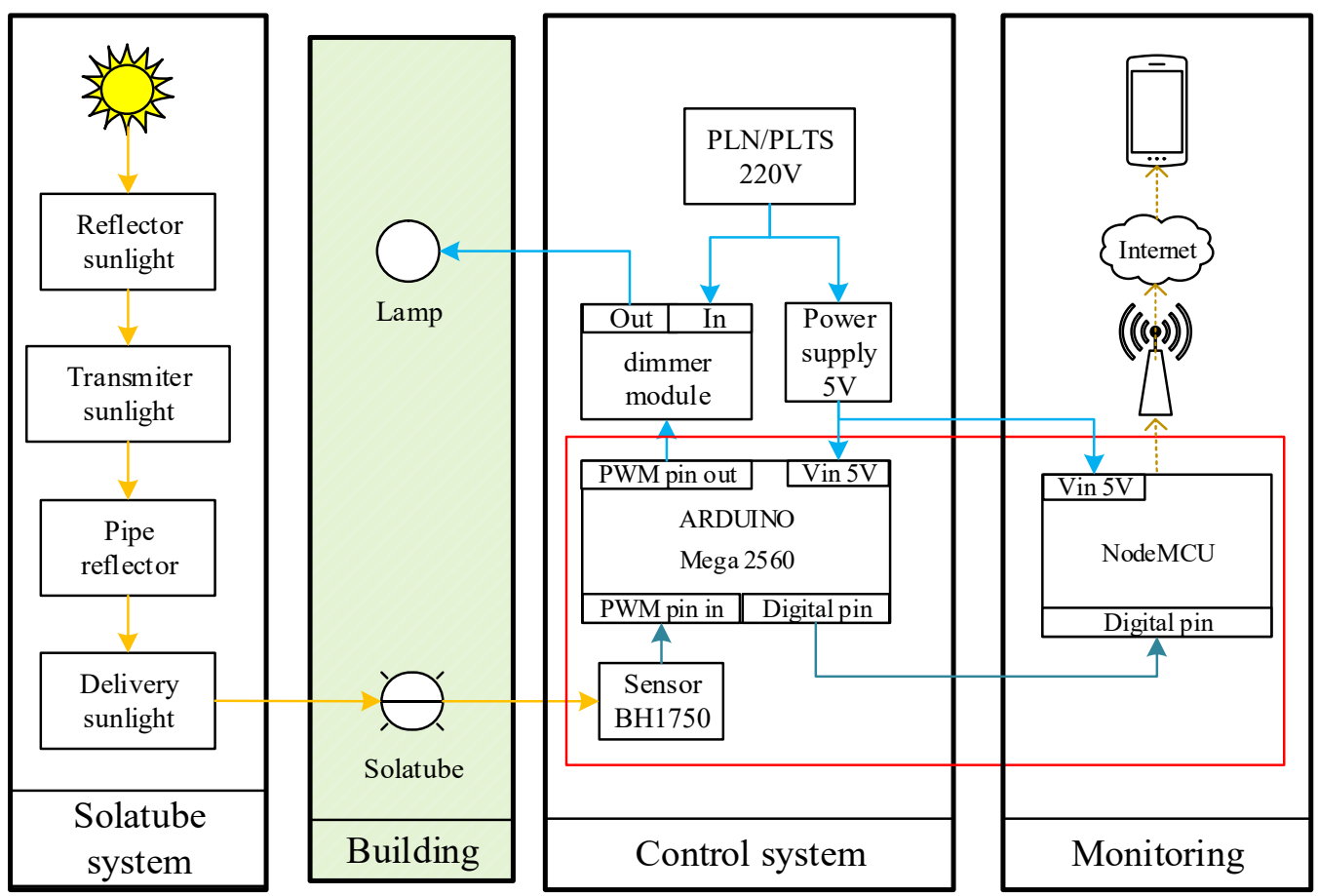

Figure 1. Block Diagram of the System
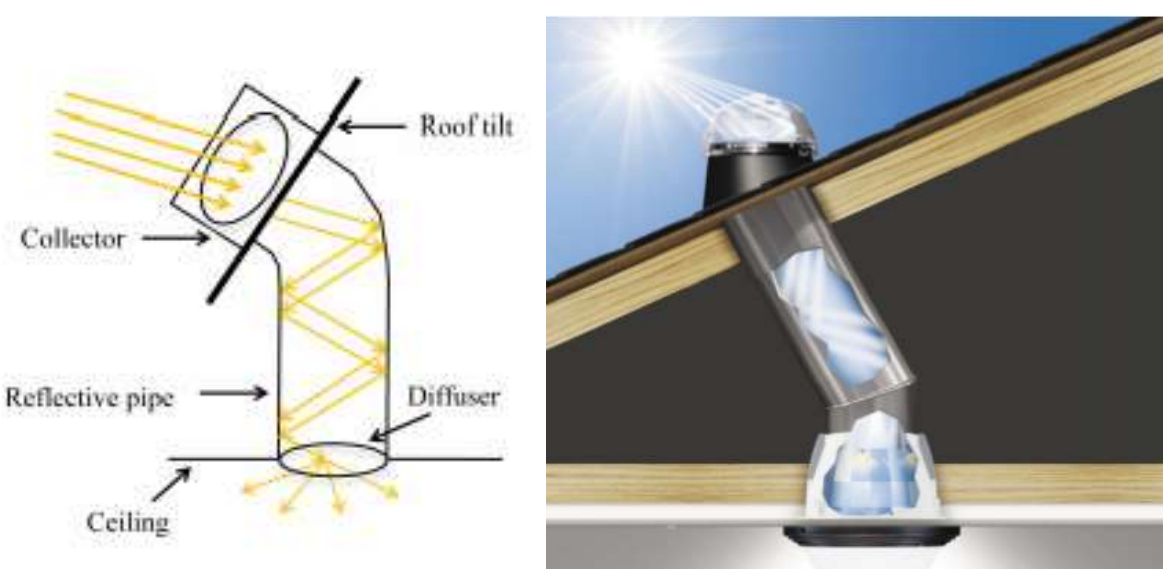

Figure 2. Solatube Construction

\subsubsection{Building}

In this study, room lighting source use combination of solatube and lamp. The value of the light intensity produced by the solatube will affect the activation of the light load. The load value used by the lamp will automatically depend on the lux value generated by the solatube. For example, the result of the solatube system has an indoor light intensity value of 0 to 350 lux, so the command given to the lamp is not ON / OFF, but relative to $0 \%$ to $100 \%$ automatically which is regulated by the control system section to meet whole room light intensity needs. 


\subsubsection{Control System}

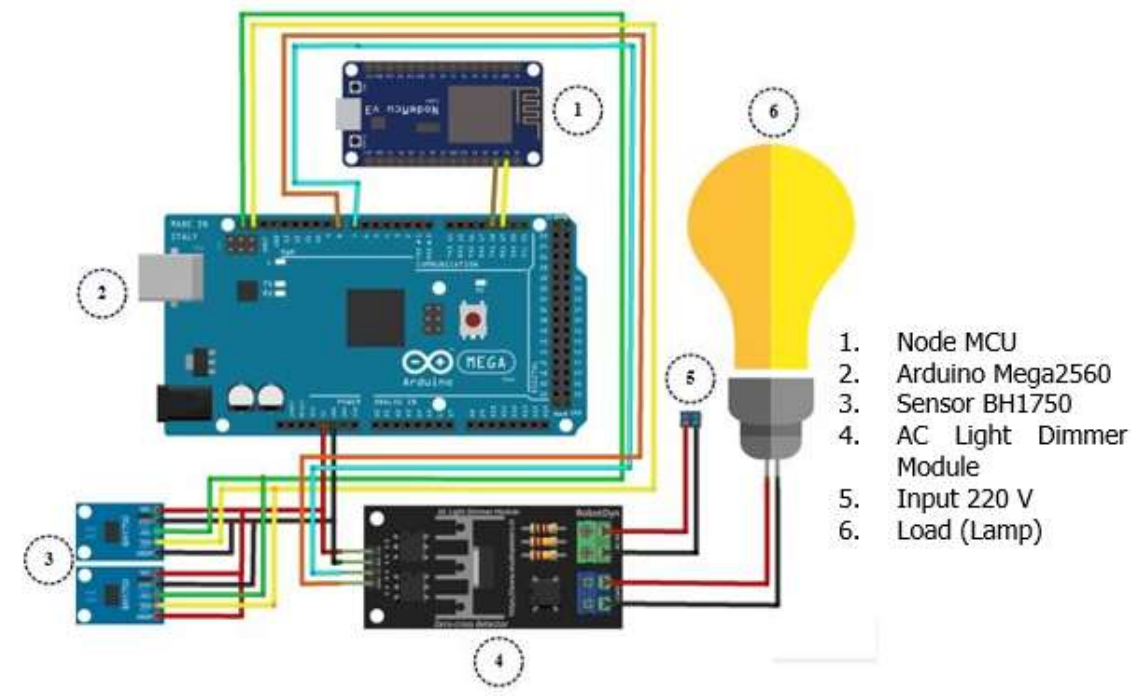

Figure 3. Control System Circuit

Figure 3 shows the dimmer control circuit. Sensor BH1750 will read the value of the solatube output light intensity to give orders to the dimmer according to data processing on the Arduino to reduce the input voltage to the lamp so the lamp light is lower so it saves the use of electric power. The BH1750 sensor will send a PWM signal, then it will be control system set point to be processed by the Arduino mega2560 as a microcontroller, the value read by the $\mathrm{BH} 1570$ sensor is already in lux units. Method used by this system is the mapping method, where the intensity value read by the $\mathrm{BH} 1750$ sensor is a readable relative light intensity value, which is between 0 to 3000 lux. The output from data processing on the Arduino will send a PWM signal to the AC Light Dimmer module as a voltage regulator module automatically depending on the value read by the $\mathrm{BH} 1750$ sensor to meet the needs of room light intensity.

\subsubsection{Monitoring System}

The function of the monitoring system is as a remote monitoring tool from the results of the solatube system which represents the light level and the percentage of lamp load. Online monitoring system itself can be used to monitor stable lighting needs, such as Traffic Lighting System, Poultry Industry, Plants Growths, and Museum Lighting System (Kumar \& Jatoth , 2015). The interface process in this study uses Nodemcu hardware to transmit data to the internet. Then Blynk as software on the user's smart phone will display it, so the users can find out the state of the room and the percentage of its load for 24 hours in real time.

The data displayed in the online monitoring system is the percentage of lamp load used in accordance with the instructions given by the dimmer as a result of reading the light intensity output of the solatube. Determination of the percentage of load usage is done using a comparison of the lamp load and the dimmer input load as shown in Equation 1.

$$
\% \text { Load }=\frac{\text { Lamp Load }}{\text { Dimmer input load }} \times 100 \%
$$

\subsection{Lighting Standard}

Natural light during the day must be utilized as well as possible, in the utilization of natural light, the entry of direct solar radiation into the building must be kept to a minimum. In addition, the heat arising from sunlight must also be kept to a minimum so it not disturb the comfort of the room. Sunlight as daytime natural lighting in buildings must comply with the 
provisions of SNI 03-2396-2001 concerning "Designing procedures for natural daylight lighting for homes and buildings", including regulating the level of light reflection and glare index. Meanwhile, the lighting system setting itself is regulated in SNI 03-6197-2000. Table 1 shows the lighting standards according to SNI 03-6197-2000.

Table 1. Lighting Standard According to SNI

\begin{tabular}{|c|c|c|c|c|c|}
\hline \multirow[b]{2}{*}{ Fungsi ruangan } & \multirow{2}{*}{$\begin{array}{c}\text { Tingkat } \\
\text { pencahayaan } \\
(\text { Lux }) \\
\end{array}$} & \multirow{2}{*}{$\begin{array}{c}\text { Kelompok } \\
\text { renderasi } \\
\text { warna }\end{array}$} & \multicolumn{3}{|c|}{ Temperatur warna } \\
\hline & & & $\begin{array}{c}\text { Warm whife } \\
<3300 \mathrm{~K}\end{array}$ & $\begin{array}{c}\text { Ccol white } \\
3000 \mathrm{~K}-5300 \mathrm{~K}\end{array}$ & $\begin{array}{l}\text { Daylight } \\
>5300 \mathrm{~K}\end{array}$ \\
\hline \multicolumn{6}{|l|}{ Rumah tinggal: } \\
\hline Teras & 60 & 1 atou 2 & - & $\bullet$ & \\
\hline Ruang tamu & $120-150$ & 1 atau 2 & & + & \\
\hline Ruang makan & $120-250$ & 1 atau 2 & $\bullet$ & & \\
\hline Ruang kerja & $120-250$ & 1 & & $\bullet$ & + \\
\hline Kamar tidur & $120-250$ & 1 atau 2 & $\bullet$ & $\bullet$ & \\
\hline Kamar mandi & 250 & 1 atau 2 & & $\bullet$ & 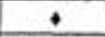 \\
\hline Dapur & 250 & 1 atau 2 & $\bullet$ & $\bullet$ & \\
\hline Garasi & 60 & 3 atau 4 & & 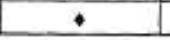 & $\bullet$ \\
\hline \multicolumn{6}{|l|}{ Perkantoran : } \\
\hline Ruang Direktur & 350 & 1 atau 2 & & 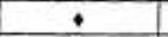 & $\bullet$ \\
\hline Ruang kerja & 350 & 1 atau 2 & & $\bullet$ & $\bullet$ \\
\hline Ruang komputer & 350 & 1 atau 2 & & + & + \\
\hline Ruang rapat & 300 & 1 & $\bullet$ & + & \\
\hline Ruang gambar & 750 & 1 atau 2 & & + & + \\
\hline Gudang arsip & 150 & 1 atau 2 & & + & + \\
\hline Ruang arsip aktif & 300 & 1 atau 2 & & + & + \\
\hline
\end{tabular}

Based on Table 1, the highest level of lighting required for most rooms in the office is 350 Lux so that in this study the set points determined are following this value.

\subsection{Implementation of the System}
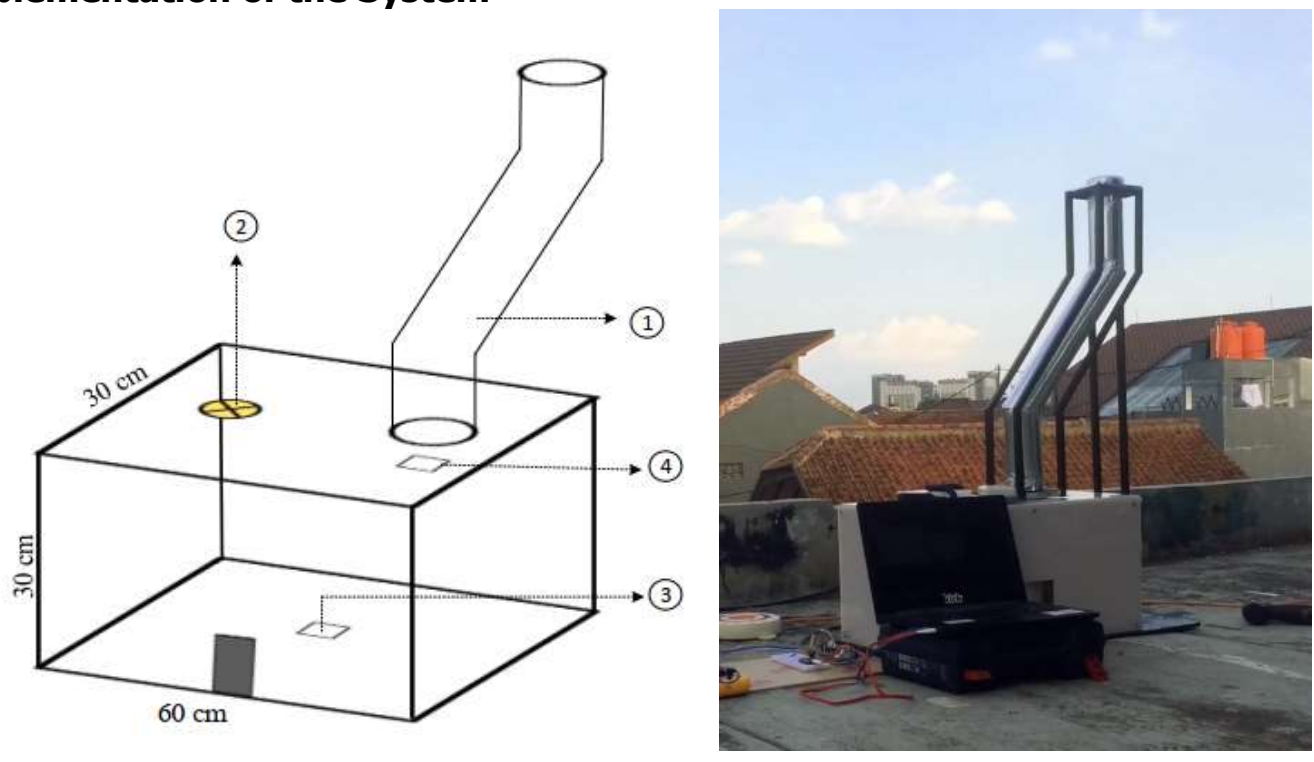

Figure 4. Implementation of Solatube System

Figure 4 shows implementation of the solatube system. The frame is made using iron. Then the chamber is made using closed acrylic material with size $60 \times 30 \times 30 \mathrm{~cm}$ to simulate a room without light ventilation, for example an underground building or other area of the room that is not exposed to direct sunlight. The lighting system consists of 2 points of light which is 
a combination of a 5 Watt lamp capacity and a solatube output which produces a total light intensity of about $350 \mathrm{Lux}$. The solatube hole size is $8 \mathrm{~cm}$ with height of $50 \mathrm{~cm}$. Figure 5 shows image of the inside chamber and position of the sensor.

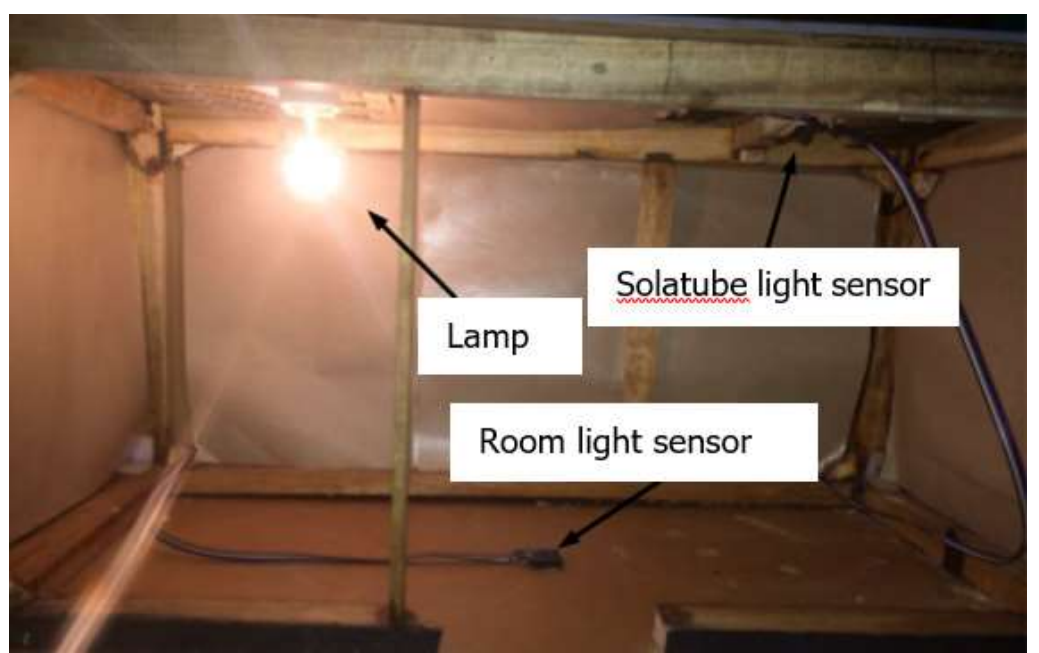

Figure 5. Position of the Sensor inside the Chamber

\section{RESULT AND ANALYSIS}

\subsection{Solatube Testing Result}

Table 2 shows the results of system testing at 24 hours with data retrieval every 2 hours. The lux value generated by the solatube will be compared with the room lux so that the percentage of light according to the set point is achieved the room light intensity needed.

Table 2. Testing Result

\begin{tabular}{|c|c|c|c|c|c|c|}
\hline \multirow{2}{*}{ Time } & \multicolumn{2}{|c|}{ Dimmer Voltage (V) } & \multicolumn{2}{|c|}{ Light Intensity (Lux) } & \multirow{2}{*}{$\begin{array}{l}\text { Load } \\
\text { Current (A) }\end{array}$} & \multirow{2}{*}{$\begin{array}{l}\text { Load } \\
\text { Percentage (\%) }\end{array}$} \\
\hline & Vinput & VOutput & Solatube & Room & & \\
\hline 00.00 & 219 & 219 & 0 & 343 & \multirow{12}{*}{0,7} & $100 \%$ \\
\hline 02.00 & 221 & 220 & 3 & 348 & & $99 \%$ \\
\hline 04.00 & 218 & 217 & 4 & 344 & & $99 \%$ \\
\hline 06.00 & 222 & 175 & 79 & 355 & & $79 \%$ \\
\hline 08.00 & 219 & 30 & 300 & 361 & & $14 \%$ \\
\hline 10.00 & 217 & 26 & 325 & 353 & & $12 \%$ \\
\hline 12.00 & 221 & 1 & 353 & 360 & & $1 \%$ \\
\hline 14.00 & 219 & 50 & 320 & 352 & & $23 \%$ \\
\hline 16.00 & 216 & 120 & 210 & 342 & & $56 \%$ \\
\hline 18.00 & 219 & 150 & 60 & 350 & & $68 \%$ \\
\hline 20.00 & 217 & 216 & 3 & 359 & & $99 \%$ \\
\hline 22.00 & 219 & 219 & 0 & 355 & & $100 \%$ \\
\hline
\end{tabular}

According to Table 2, based of weather conditions in the morning until late afternoon can produce significant light intensity at 06.00 to 16.00 . Where the light intensity peaks from the sun at 12.00 is 353 Lux and made the lamp almost have 0 load. While at 18.00 to 04.00 there is lower light intensity until it disappear or nearly 0 lux. Solatube succeeded in helping savings energy consumption from 06.00 to 18.00 with an average of 235,3 Lux for 12 hours in one 
day. The state of the light intensity value in the room is sufficient stable with an average of 353,3 Lux at that time.

Based on the output voltage from the table 2, the AC light dimmer module is successfully processed by the BH1750 and Arduino Mega2560 sensors. Where the load output voltage on the $\mathrm{AC}$ light dimmer has some relative voltage values between $1 \mathrm{~V}$ to $175 \mathrm{~V}$ along 12 hours. Because the AC light dimmer module has a triac component that changes voltage of the load, while the current from the input to the load does not change significantly with an average of 0.7 Ampere so the percentage of load generated by the system run into several changes that are caused depending on the results of light intensity from the solatube effectively in 12 hours at $1 \%$ until $79 \%$ or in average $36,1 \%$. It can be said that the system can saved energy around $63,1 \%$ along 12 hours from 6.00 until 18.00 .

Figure 6 shows a graph of the load voltage against the output light intensity value of the solatube where the load voltage is the input given to the lamp according to the light intensity needed to achieve the desired Lux value of the room, which is 350 Lux. It can be seen that the higher the solatube light intensity value, the lower the load voltage even reach almost zero $\mathrm{V}$. The comparison value then becomes the basis for calculating the percentage of the load that will be output to the online monitoring system so that it can be seen how much energy savings can be made with the Solatube system.

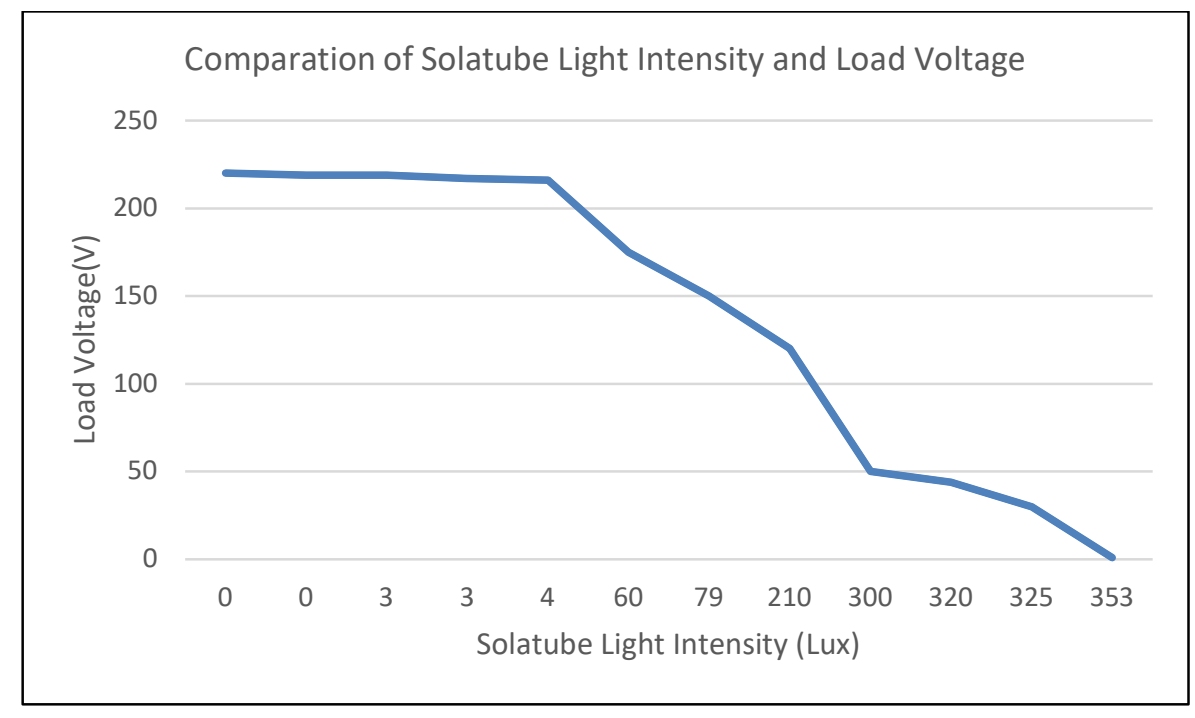

Figure 6. Comparation of Solatube Light Intensity and Load Voltage

Figure 7 shows a graph of the load percentage in 24 hours. This shows that the minimum electrical energy used for the lamp is at midday because the required light intensity value has been fulfilled by the light from the solatube. The greatest load is seen at night on 20.00 to 04.00 , at around $100 \%$. The use of loads is decreases at the time from 06.00 to 12.00 , then the it starts to rises from 13.00 to 18.00 along the sun light decreases and finally reach $100 \%$ at night. It can be seen that sunlight effectively helps lighting for 12 hours for power saving although sunshine did not be fully able to provide lighting every day, especially when it is cloudy, rainy or even at night. 


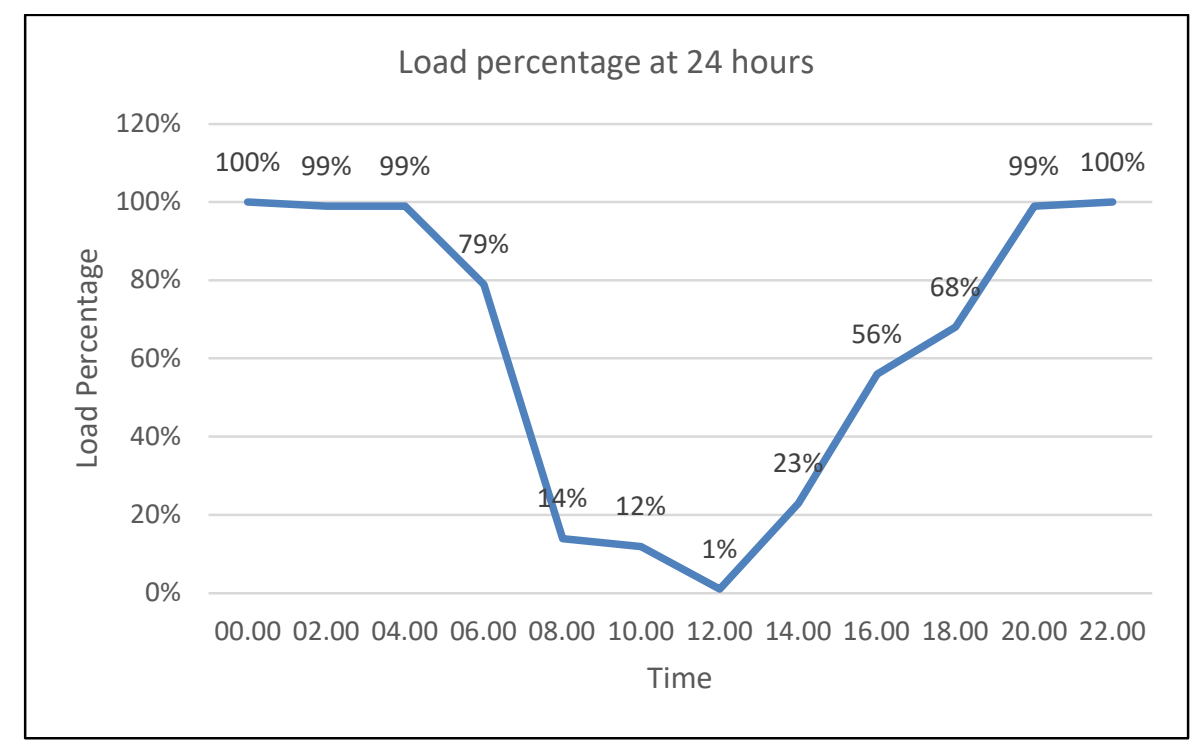

Figure 7. Load Percentage in 24 Hours

\subsection{Monitoring Testing Result}

Figure 8 shows an online monitoring system interface that can be accessed via a mobile phone connected to the internet. So that load usage data can be monitored in real time. This monitoring system can also be used as a data logger to monitor and evaluate use of electricity for lighting. The value of the solatube light display is the result of real time reading of the output of the solatube by the $\mathrm{BH} 1750$ sensor, while the percentage of the load shows the ratio of the value of the solatube light with the light intensity of the room so that the percentage of light output from the lamp is obtained as needed.

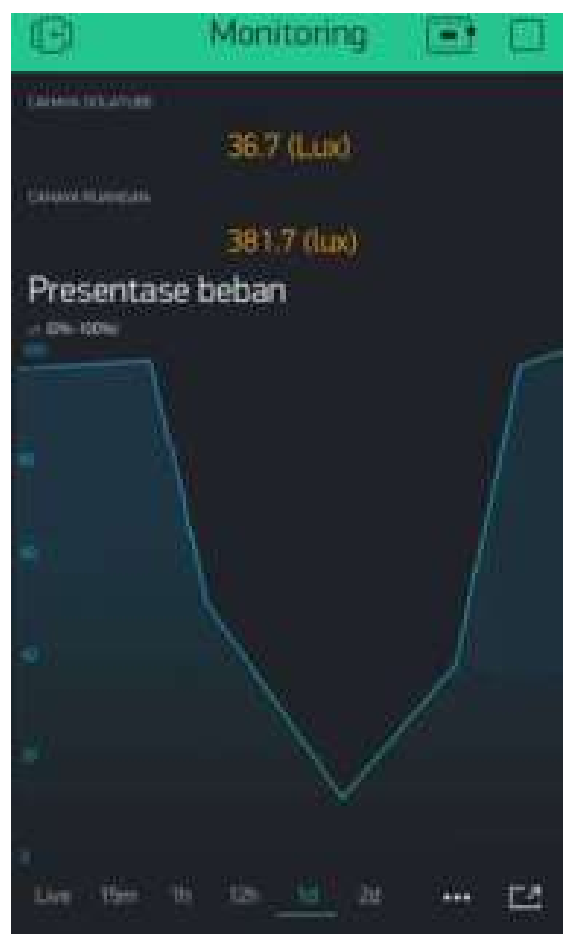

Figure 8. Online Monitoring Interface 
Light intensity value on the solatube as a regulator of lamp load activation will change every second depending on results of the incoming sunlight intensity. While the value of light intensity in the room will be around 350 Lux. So it is very important to have online data logger for long time load monitoring.

\section{CONCLUSION}

Based on the test results, the solatube system can produce a maximum light intensity value that can meet the standards for the reading room, which is more than 350 lux with the percentage of light being only $1 \%-79 \%$, especially during the use of daytime loads. This shows that with solatube lighting system, power consumption for lighting can be reduced, thereby increasing energy and cost savings. Furthermore, this tool is equipped with a data logger that can be accessed via the internet to monitor real time electricity usage thus that it can be monitored and evaluated for further development.

\section{ACNOWLEDGEMENT}

This research is fully funded by Lembaga Penelitian dan Pengabdian Kepada Masyarakat Institut Teknologi Nasional Bandung by SK Number of 353/B.05/LP2M-Itenas/V/2020.

\section{REFERENCES}

03-2396-2001, S. (2001). Tata cara perancangan sistem pencahayaan alami. Badan Standardisasi Nasional.

03-6197-2000, S. (2000). Konservasi energi pada sistem pencahayaan. Badan Standardisasi Nasional.

Alzaed, A., \& Balabel, A. (2020). Experimental Investigations of Solatube Daylighting System for Smart City Applications in Saudi Arabia. Journal of Environmental Research Engineering and Management, 76(3), 16-23.

Babarinde, T., \& Alibaba , H. (2018). Achieving Visual Comfort through Solatube Daylighting Devices in Residential Buildings In Nigeria. International Journal of Scientific \& Engineering Research, $9(1)$.

Chen, Y., Liu, J., Pei, J., Cao, X., \& Chen, Q. (2014). Experimental and simulation study on the performance of daylighting in an industrial building and its energy saving potential. Energy and Buildings ,73, 184-191.

Chi, D., Moreno, D., \& Navarro, J. (2018). Correlating daylight availability metric with lighting, heating and cooling energy consumptions. Building and Environment.

Hodges, A. (2017). Light Sensing Automatic Blinds. Electrical Engineering Department California Polytechnic State University. 
Iqbal, I., \& Ahmed, I. (2014). Energy saving potential in buildings for Karachi climate using daylight. 2014 International Conference on Energy Systems and Policies (ICESP). Islamabad: IEEE.

Ji, S., Cao, G., Zhang, J., Yu, F., Li, D., \& Yu, J. (2016). Lighting design of underground parking with tubular daylighting devices and LEDs. Optik, 1213-1216.

Kumar Singh, V., \& Kumar Jain, A. (2013). Modifying The Design Of Solar Tube To Produce Cost Effective Dispose Of Sunlight In Multi-Storey Buildings . International Journal Of Scientific \& Technology Research, 2(2).

Kumar, N., \& Jatoth , R. (2015). Development of cloud based light intensity monitoring system using raspberry Pi. International Conference on Industrial Instrumentation and Control (ICIC) (pp. 1356-1361). Pune: IEEE.

Nizam Kamaruzzaman, S., Edwards, R., \& Ahmad Zawawi, E. (2015). Achieving energy and cost savings through simple daylighting control in tropical historic buildings. Energy and Buildings, 90, 85-93.

Susanto, D., Febrianti Rahayu, G., \& Widyarko. (2018). Daylight Analysis in Low-Cost Apartments in Jakarta. 2nd International Conference on Smart Grid and Smart Cities (pp. 21-25). Kuala Lumpur: IEEE.

Wachenfelt, H. v. (2015). Lighting Energy Saving with Light Pipe in Farm Animal Production. Journal of Daylighting, 2, 21-31.

Wong, I. L. (2017). A review of daylighting design and implementation in buildings. Renewable and Sustainable Energy Reviews, 74, 959-968.

Young Shin, J., Young Yun, G., \& Tai Kim, J. (2011). Evaluation of Daylighting Effectiveness and Energy Saving Potentials of Light-Pipe Systems in Buildings. Indoor Built Environ., 21(1), 129-136.

Zheng, T., Wujun, Zhou, Z., \& Yan, W. (2019). Smart Lighting with Autonomous Color Tunability. 16th China International Forum on Solid State Lighting, (pp. 256-259). Shenzen: IEEE. 